\title{
Analyzing the Economic Impact of Foreign Employment on Development Prospective of Nepal
}

\begin{abstract}
Foreign employment has become one of the major sources of households' income for Nepalese society. Nepal has become one of the major labors exporting country. After 1990s, remittance is playing a crucial role for foreign currency earnings and favorable impact on balance of payment situation, to reduce the number of people in the country below the poverty line and ultimately to the economic growth of the nation. This paper tries to examine the economic impact of foreign employment on remittance as well analyze the growth and trends of foreign employment and remittance on development prospective in Nepalese economy. Some descriptive statistics such as percentage, ratio, pie-chart, bar diagram and line chart are used to explain the growth and trends of foreign employment as well as situation of remittance in Nepal. Correlation and linear regression model are used to analyze the impact of foreign employment on remittance. The inflow of remittance growth rate has positive association along with significant contribution of remittance to Gross Domestic Product in Nepalese economy. Also, foreign employment has important effect on remittance. Foreign employment is one of the effective instruments for poverty alleviation and social changes.
\end{abstract}

Keywords: Foreign employment, Economic Impact, Remittance, Nepalese Economy.

\section{Introduction}

Foreign Employment means going from one country to another country for job and to earn money. Foreign employment of people has been a usual phenomenon since the beginning of human civilization. Gradually the foreign employment took the shape in diverse form and now has become a very essential and common in each and every corner of the world. Millions of people from around the world are leaving their usual place of residence for seeking better employment opportunities and improve the living standard of their dependents. Globalization and integration of regional economies have added impetus to the growing mobility of workers across borders. Poverty and the inability to earn enough as well produce enough to support oneself or a family are major reasons behind the movement of work seekers from one place to another. These are not only characteristics of foreign employment from poor to rich states,

\footnotetext{
* Associate Professor of Economics Tribhuvan University E-mail: kharelkhom @yahoo.com

** Assistant Professor of Rural Development Tribhuvan University E-mail: sskharel@gmail.com
} 
poverty also fuels movement from one developing country to others where work prospects seem-at a distance, at least-to be better.

The history of foreign employment in Nepal dates back to the early Nineteenth century when Nepalese soldiers began to work for the British army. In the ensuing decades thousands of Nepalese youths had worked in British and Indian army. Currently, over 60 thousand Nepalese are working in the Indian Army and other government institution in India. There are three migration patterns in Nepal are: domestic migration, migration to India and migration to third countries other than India. As the border between Nepal and India is open, thousands of Nepalese people go to India for labor employment. It increased dramatically after 1996 and the consequent of shrinking economic opportunities at home compelled Nepalese youths to look for alternatives elsewhere. The massive unemployment insides the country is main reason behind this upsurge in venturing out to distant lands. India has been a traditional destination for Nepalese migrants. The primary reasons for these are geographical proximity, historical and cultural links, and a large and open porous border. The 1950 Treaty of Peace and Friendship between India and Nepal formalized free border movement of people. The bulk of these migrants are employed in the private and informal sectors.

These migrants holding semi-skilled and unskilled jobs in restaurants and factories are also employed as domestic workers, security guards, and maids. However, a significant proportion of the remittances from India are not recorded in the balance of payment as they are brought in by the migrants themselves or sent through relatives and friends. As increasingly larger share of remittances now comes from countries other than India, reflecting changing migration patterns and higher earnings in these locations. Moreover, the composition of skills of the labor flows is different among destinations. While migrants to the Middle East are employed mostly as security personnel, chauffeurs, and construction workers, the demand from South East Asian countries is more for employment in industrial enterprises.

There are huge number of Nepalese in UK and USA. They went to those countries as a student but their return to Nepal is rare. They are remitting their earning through unofficial channels since the commission charge in official channels is very high. The scale of foreign labour migration and remittances in Nepal is staggering and foreign employment provides one of the best hopes of inclusive development for the country in the future.

\section{Research Review}

The history of remittance in Nepal began after the British-India and Nepal war during 181416. Since then, Nepalese youths used to be recruited in the British national army (Thieme, 2004). The volumes of remittance increased only after 1995, when the civil conflict destroyed the local labour markets and people started looking for overseas employment. The political turmoil blocked the industrial expansion and halted plenty of small medium enterprises all over the country reducing job opportunities (Miller \& Thieme, 2007). 
Remittance is typically helpful to meet specific needs of the respondent's family members and thus tend to increase their standard of living. In lower class and poor household, they may use their remittances to fulfill their basic needs, such as in consumption, housing, children education and health care and to pay for loan. In middle class and rich households, they may provide either loan for individuals going aboard or capital for business and entrepreneurial activities. From macroeconomic point of view, this source may be more stable than capital flows (Gaudel, 2006).

The number of Nepalese foreign employment has been growing over time and most of rural households now rely on at least one member's earning from employment away from home. Nepalese workers have sought foreign employment as both the agricultural and nonagricultural sectors within the country struggle to generate new employment opportunities, with limited arable land, landlessness is pervasive and the number of landless households has steadily increased in the agricultural sector. In the non-agricultural sector, the slowdown in growth, especially since 2000/01, due to the Moist insurgency and exogenous shock further retarded the pace of employment creation. The conflict had also created difficult living and security conditions, especially in the rural areas in that period. It had also promoted people to look for overseas employment (Panta, 2011).

Kafle (2018) analyzed the relation between remittances received and economic growth in Nepal. There was a long run association between remittance, trade and economic growth. Moreover, finding indicates that the relation between remittance and economic growth is not significant in the short run. As results suggest an absence of short-run causation from remittances to GDP, but there exists long-run relationship between economic growth and remittance earning.

Emigration can reduce output growth and exacerbate incentives to emigrate. Reduced economic activity from labour outflows could dampen tax revenue (Gibson \& Mckenzie, 2012), while remittance inflows could raise consumption-based tax receipts or reduce labour tax revenue by affecting labour decisions (Ebeke, 2010).

Sending remittance in Nepal from aboard through banking channel has become efficient and easy. It is now possible to measure the amount repatriated by the Nepalese migrant from aboard to Nepal every year through formal channel. However, it is estimated that only $40 \%$ of Nepalese migrants workers use formal channel to send their earning back home. The rest still rely on the informal channels like Hundi that is believed to be fast and economical. Workers remittance is now considered as backbone of Nepalese economy. Shrestha (2008) remarks that revenue support for remittances have emerged as one of the premier sources of foreign exchange and important avenue of support for family members.

Since last few years, remittance income is playing a vital role for foreign currency earnings and favorable impact on balance of payment situation, to reduce the number of people in the country below poverty line and ultimately to the economic growth of the nation. Foreign 
employment has proved that it is one of the major sources for raising economic status of the people and instruments of social development. There is need for a comprehensive study toward foreign employment and remittance of Nepal.

\section{Research Problems \& Objectives}

Nepal has a long history of emigration and it is in increasing trends till date. The contribution of remittance in share of GDP has increased, poverty level has decreased, the education and health sectors have been improved gradually but level of development is in slow pace and at the same time trade deficit has increased significantly. Remittances stimulate household's status and social development. By properly mobilizing the remittances in economic development activities, Nepal can ensure long-term income general in the nation. Though, the remittances have not been properly mobilized in income generating and productive sectors yet. Besides this, there are no effective emigration policies due to the lack of proper research and in one side and less government interest in other in this field. Therefore, there is need to conduct a study on management of international migration keeping national interest in high priority and identify the specific areas for mobilizing remittances in development sectors.

The basic objective of the paper is to explore the current situation of foreign employment status of Nepal and to analyze the economic impact of foreign employment on remittance and social development.

\section{Research Methodology and Database}

This paper is based on secondary data and descriptive research design is applied to analyze the data. All analysis and discussion is based on published sources of secondary data such as Economic Surveys (2001/02-2018/19), Report of Foreign Employment Department (2019), Quarterly Economic Bulletin (2019) published by Nepal Rastra Bank among others. Various research documents have been reviewed for analyzing the social development of Nepal due to the foreign employment. Some descriptive statistics such as percentage, ratio, pie-chart, bar diagram and line chart are used to explain the growth and trends of foreign employment as well as situation of remittance in Nepal. The economic impact of foreign employment has been analyzed on remittance, contribution to GDP, employment and socio-economic changes. Correlation is applied to show the relationship between foreign employment and remittance inflow and simple linear regression model has been used to measure the impact of foreign employment on remittance inflow.

\section{Results and Discussion}

For the basis of contribution to employment, economic opportunity, poverty reduction, remittance and national economic development, foreign employment is being very one of the key sectors. Further, foreign employment is also an attractive sector for $3 / 4^{\text {th }}$ adult those are entering into labour market every year. Since the last decades, more than 1000 youth are going foreign labour market each day only for foreign employment. Nepalese Foreign Employment Act 1985 made provisions for the matters relating to foreign employment 
such as counseling, complain and compensation. National Labour Policy 1999 has dealt the government policies and programs on different labour issues where the issue regarding the promotion and reliability of international labour migration is also highlighted to some extent. The Labour and Employment Policy 2005 faced the existing challenges by exploring and tapping the new opportunities and potentials of the labour and employment sectors. The policy aimed to promote production-oriented employment by eliminating forced labour practices and make the just, healthy and cardinal labour-related development.

\section{Major Destinations of Foreign Employment}

Nepalese labors are demanded mostly in countries like Malaysia, Qatar, Saudi Arabia and UAE. Most of the Nepalese labors ranging from unskilled, semi-skilled and skilled are equally opting to receive foreign employment to these countries. Table- 1 shows the top ten destinations of Nepalese labors.

Table-1: Foreign Employment Status upto 2019/20 March

\begin{tabular}{|l|c|c|c|c|}
\hline Country & Male & Female & Total Workers & Percentage (\%) \\
\hline Malaysia & 133233 & 30486 & 1362824 & $28.44 \%$ \\
\hline Qatar & 127923 & 21788 & 1301027 & $27.15 \%$ \\
\hline Saudi Arabia & 957652 & 8658 & 966310 & $20.16 \%$ \\
\hline UAE & 620082 & 67210 & 687292 & $14.34 \%$ \\
\hline Kuwait & 122703 & 44029 & 166732 & $3.50 \%$ \\
\hline Bahrain & 54930 & 4905 & 59835 & $1.25 \%$ \\
\hline South Korea & 40938 & 2176 & 43114 & $0.89 \%$ \\
\hline Others & 147334 & 57628 & 204962 & $4.27 \%$ \\
\hline Total & $\mathbf{4 5 , 5 5 , 2 1 6}$ & $\mathbf{2 , 3 6 , 8 8 0}$ & $\mathbf{4 7 , 9 2 , 0 9 6}$ & $\mathbf{1 0 0 \%}$ \\
\hline
\end{tabular}

Source: Economic Survey 2019/20.

Upto the FY 2019/20, 47 lakh 92 thousand and 96 workers had gone for foreign employment. Among them, 45 lakh 55 thousand 2 hundred and 16 were male (i.e.,95.06\%) and 2 lakh 36 thousand 8 hundred and 80 were female (i.e.,4.94\%). Table 1 shows that Nepalese labors give first priority to Malaysia, second to Qatar, third to Saudi Arabia, fourth to UAE, fifth to Kuwait and sixth to Bahrain and so on. For more clarity the above information is presented in Figure-1. 
Figure-1: Percentage of Foreign Employment Status in Top Destination Countries

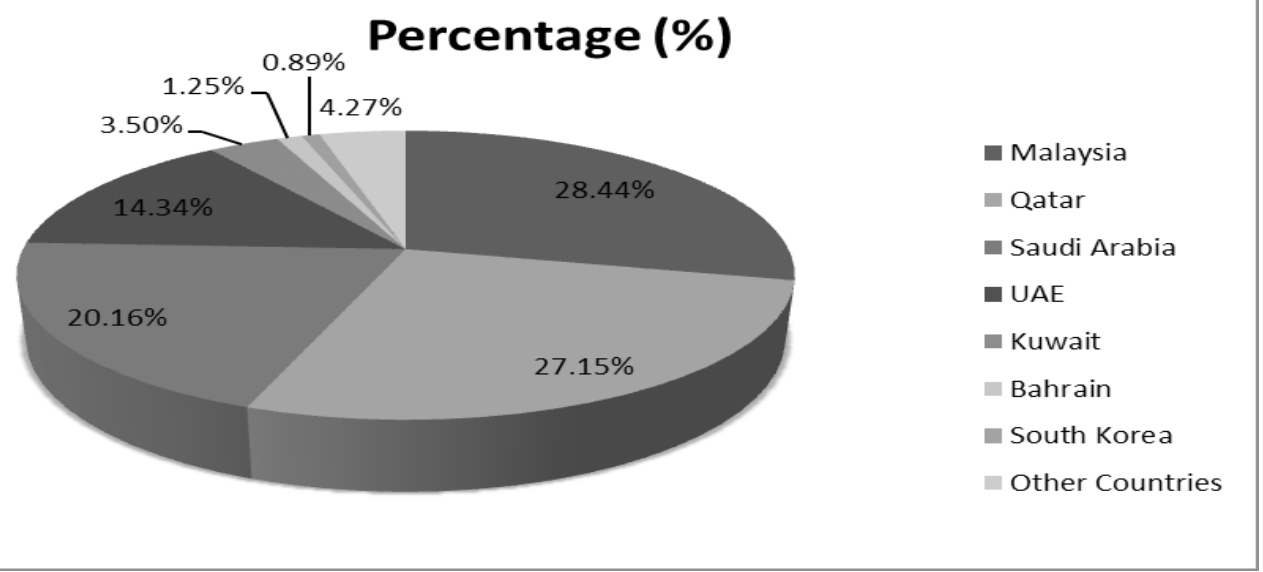

The Pie Chart shows that Malaysia, Qatar and Saudi Arabia are the main destinations of Nepalese labors.

\section{Growth Trends of Foreign Employment and Remittance in Nepal}

Over the past 18 years from 2001, foreign employment and international migrant's remittances have become increasingly prominent in our country. The number of remittances reflects only transfer record in the balance of payments. The Appendix-I shows foreign employment and the remittance income from fiscal year 2002/03 to 2018/19. Figure-2 depicts the growth trends rate of foreign employment and flow of remittance from fiscal year 2002/03 to 2018/19.

Figure-2: Growth Trends of Foreign Employment and Remittance from 2002/03-2018/19.

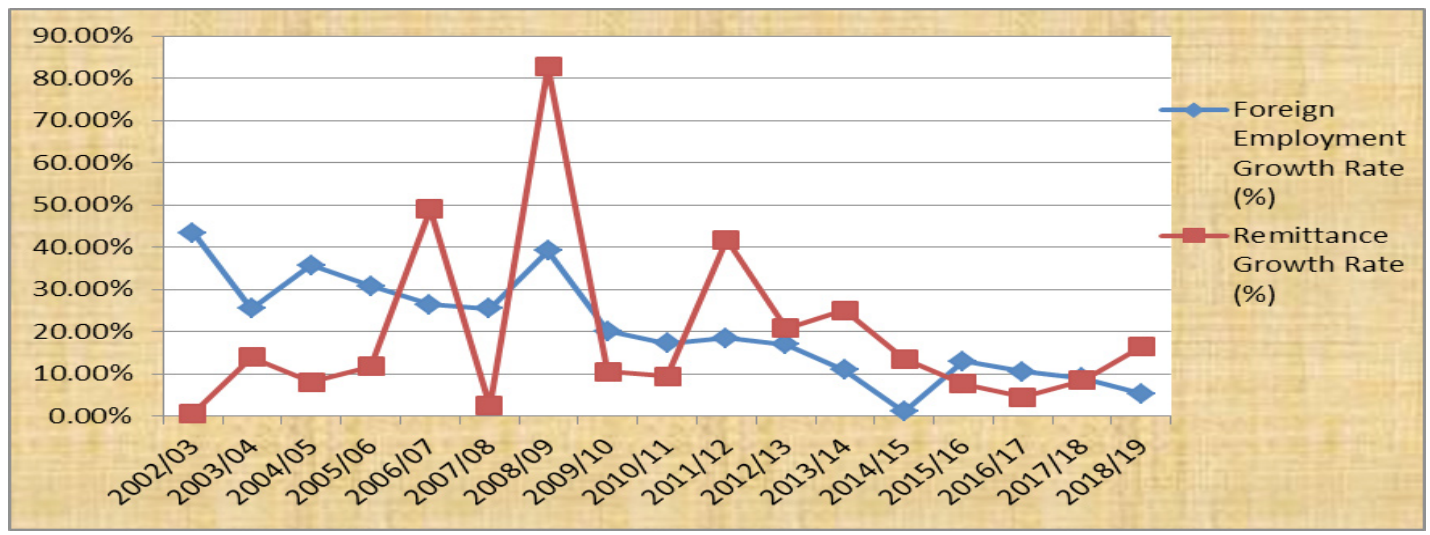


In the all most years, there was increment of foreign employment and remittance flow in Nepal. The highest growth rate of foreign employment was 39.24 percent in the fiscal year $2008 / 09$ and the lowest growth was in the fiscal year 2014/15. Similarly, the growth rate of remittance flow was the highest $(82.75 \%)$ in the fiscal year 2008/09 and the lowest rate was in the $2007 / 08$.

\section{Contribution of Remittance to Gross Domestic Product (GDP)}

Since last few years, remittance is playing a vital role for foreign currency earnings and favorable impact on balance of payment situation, to reduce the number of people below poverty line in the country and ultimately increase economic growth of the nation. The Appendix-I reveals the ratio of remittance to GDP from the fiscal year 2001/02 to 2018/19. Appendix-I shows the ratio of remittance to Gross Domestic Product (GDP) from 2001/02 to 2018/19. There is significant contribution of remittance to GDP in Nepalese economy. The average ratio of remittance and GDP seems to be 20 percent during the study periods.

Figure-3: Contribution of Remittance Ratio to GDP from 2001/02-2019/20

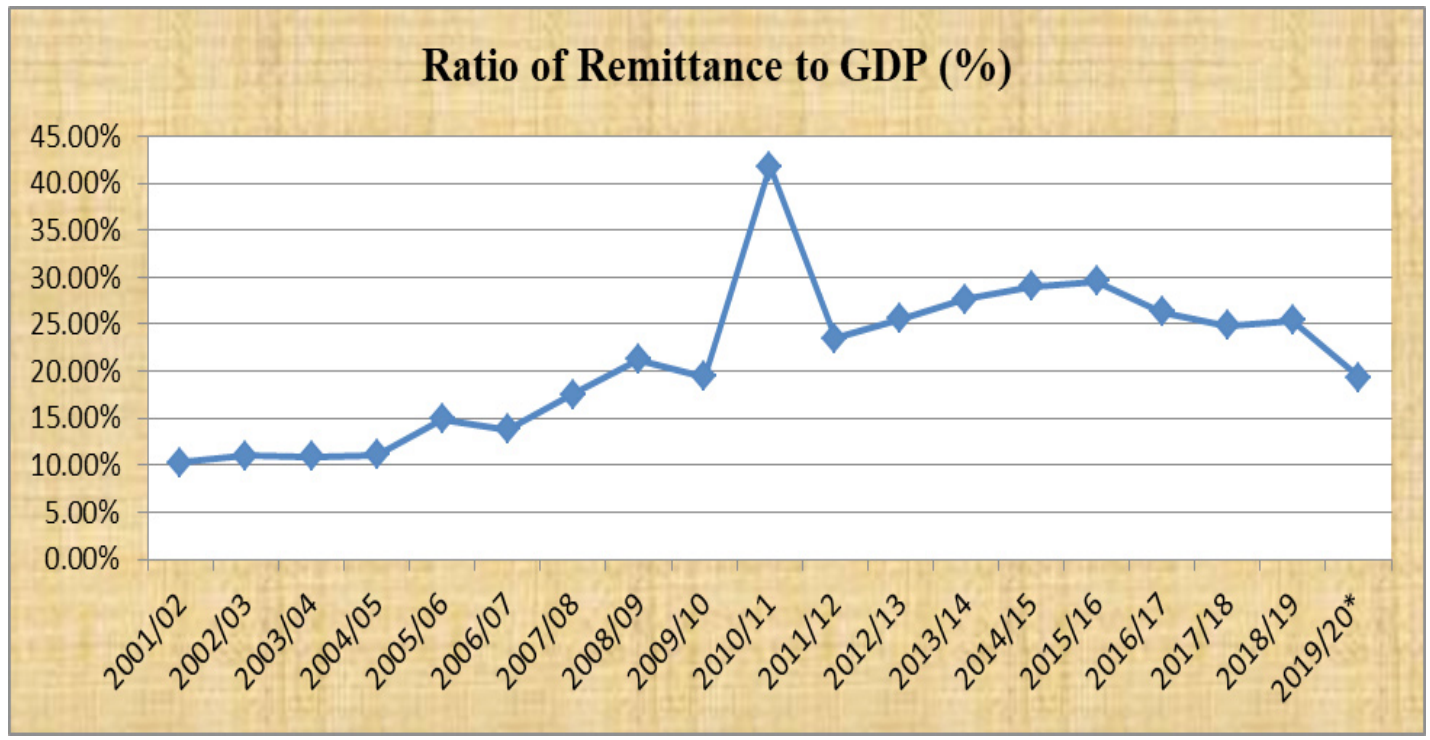

Figure- 3 shows the ratio of remittance to GDP percentage which has an increasing tendency from fiscal year 2001/02 to 2019/20.

\section{Impact on Balance of Payment (BoP) and Foreign Exchange Reserves}

The increase in remittance income boosted the country's foreign exchange reserve as well as put the country's overall balance of payment (BoP) into surplus. The trade deficit of Nepal has been increasing each year. Upto March, 2019/20, trade deficit was Rs.849.33 billion which was Rs.887.88 billion in the same period in the previous year. The balance of payment (BoP) recorded a surplus of Rs. 37.84 billion during mid-March 2019/20 against the deficit of Rs. 
58.99 billion during the same period of the previous FY 2018/19. Current account balance which had been in deficit of Rs. 191.49 billion till mid-March during the FY 2018/19, recorded the deficit of Rs. 124.93 billion during mid-March of FY 2019/20. High growth rate of import is the major cause for the increase in the size of deficit in both current account and BOP.

Remittance inflow recorded a notable growth of 1.8 percent to Rs. 592.42 billion during the mid-March of FY 2019/20. In the same period of the previous FY 2018/19, it had increased by 23.4 percent to Rs. 582.19 billion. Remittance inflow has larger share in current account which was recorded 63.6 percent in the mid-March of 2019/20 which was 63.5 percent in the FY 2018/19. The share of remittance inflow to current transfer income was 87.7 percent in the mid-March 2019/20 whereas it was 87.4 percent in the 2018/19.

\section{Impact of Foreign Employment on Remittance}

Since the relationship between foreign employments to remittance has been observed in this study, further, this study also focused on examining the effect of changes in foreign employment over remittance. For hypothesis testing, regression analysis was done in SPSS. The result of correlation estimates is given in Table- 2 .

Table-2: Correlations between Employment and Remittance

\begin{tabular}{|c|c|c|c|}
\hline \multicolumn{4}{|l|}{ Correlations } \\
\hline & & Foreign Employment & Remittance in Rs.Billion \\
\hline \multirow{3}{*}{$\begin{array}{l}\text { Foreign } \\
\text { Employment }\end{array}$} & Pearson Correlation & 1 & $.987^{* *}$ \\
\hline & Sig. (2-tailed) & & .000 \\
\hline & $N$ & 18 & 18 \\
\hline \multirow{3}{*}{$\begin{array}{l}\text { Remittance in } \\
\text { Rs.Billion }\end{array}$} & Pearson Correlation & $.987^{* *+}$ & 1 \\
\hline & Sig. (2-tailed) & .000 & \\
\hline & $N$ & 18 & 18 \\
\hline
\end{tabular}

Source: Calculated by Authors based on data of Appendix-I.

There is positive correlation between foreign employment and remittance. It means, foreign employment and remittance are highly correlated each other because the value of $r$ is above 90 percentage.

The estimates of the simple linear regression are given in Table-3. From the table the value of $\mathrm{R}$ is 0.987 which indicates the highly positive relationship between foreign employment and remittance $(p<0.05)$. Similarly, $R$-square value of 0.974 states that $97.40 \%$ change in remittance is due to independent variable (Table-3). 
Table-3: Regression between Foreign Employment and Remittance

\begin{tabular}{|c|c|c|c|c|c|c|c|c|c|c|}
\hline \multicolumn{11}{|c|}{ Model Summary } \\
\hline \multirow[t]{3}{*}{ Model } & \multirow[t]{3}{*}{$R$} & \multirow{3}{*}{\multicolumn{2}{|c|}{$\begin{array}{l}R \\
\text { Square }\end{array}$}} & \multirow{3}{*}{$\begin{array}{l}\text { Adjusted } \\
R \text { Square }\end{array}$} & \multirow{3}{*}{$\begin{array}{l}\text { Std. Error of } \\
\text { the Estimate }\end{array}$} & \multicolumn{5}{|c|}{ Change Statistics } \\
\hline & & & & & & R Square & F Change & $d f 1$ & $d f 2$ & Sig. F \\
\hline & & & & & & Change & & & & Change \\
\hline 1 & $.987^{a}$ & .97 & & .973 & 47.41812 & .974 & 602.295 & 1 & 16 & .000 \\
\hline \multicolumn{11}{|c|}{ a. Predictors: (Constant), Foreign Employment } \\
\hline \multicolumn{11}{|c|}{ Coefficients $^{a}$} \\
\hline \multirow{2}{*}{\multicolumn{3}{|c|}{ Model }} & \multicolumn{3}{|c|}{ Unstandardized Coefficients } & \multirow{2}{*}{\multicolumn{3}{|c|}{$\begin{array}{l}\text { Standardized Coefficients } \\
\text { Beta }\end{array}$}} & \multirow[t]{2}{*}{$t$} & \multirow[t]{2}{*}{ Sig. } \\
\hline & & & $B$ & & Std. Error & & & & & \\
\hline \multirow[t]{2}{*}{1} & \multicolumn{2}{|c|}{ (Constant) } & \multicolumn{2}{|c|}{-71.080} & 20.078 & & -3.540 & .003 \\
\hline & \multicolumn{2}{|c|}{$\begin{array}{l}\text { Foreign } \\
\text { Employment }\end{array}$} & \multicolumn{2}{|c|}{.000} & .000 & \multicolumn{3}{|l|}{.987} & 24.542 & 2.000 \\
\hline
\end{tabular}

\section{Source: Calculated by Author based on Appendix-I}

The result shows that there is a significant impact of foreign employment on remittance. It indicates that increase in foreign employment helps improve the position of remittance. It shows a significant association between the changes in foreign employment on remittance. The finding of linear regression analysis between foreign employment and remittance indicates that foreign employment is a significant predictor of remittance.

\section{Foreign Employment for Socio-economic Development}

There is significant contribution of foreign employment on social changes and development in Nepal. Foreign employment is not only the sources of remittance but also the transformation of skill and knowledge. Foreign employment can considerably change household's income and living standard of the people. Remittances make crucial contributions to national financial stability and also to household finances where more households receive remittance income. There has been significant contribution of remittances in the reduction of poverty and boosting economic development. There is significant contribution of remittances inflow from foreign employment in poverty reduction of the related families.

The state of poverty reduction after the 1992 ( $8^{\text {th }}$ Plan) seems to be satisfactory. The achievements of poverty alleviation in different plan periods can be attributed to foreign employment and the resulting inflow of remittances. Households/Families who receive foreign remittances use them in livelihood improvements and acquire assets and capitals. This has contributed in increased financial capital, education of the children, social capital and migration specific knowledge. Before the Eighth plan, the poverty level was not systematically analyzed. There were not specific objectives in the plans for poverty reduction. Resources were allocated on different sectors without specific targets. After the success of democratic movement in 1990s, Nepal has entered into systematic process for preparing plan for poverty reduction due to which the target of poverty reduction in the Eighth plan was nearly met. In the Ninth plan 
poverty alleviation target was to bring down 32 percent from 42 percent but achievement was just 38 percent.

In the Tenth plan, target of poverty alleviation was to bring down 30 percent from 38 percent. The result was near to the target level, i.e.31 percent. In the $11^{\text {th }}$ plan, target of poverty alleviation was 24 percent from 31 percent and the achievement was near to target i.e.25.4 percent. The $12^{\text {th }}$ plan showed that the poverty alleviation target was to bring 21 percent from 25.4 percent but the poverty level was 23.8 percent in the end of the plan. The poverty level decreased from 23.8 percent to 21.6 percent in the $13^{\text {th }}$ plan, however target was to bring down 18 percent. The target of poverty alleviation was to bring down 17 percent from 21.6 percent in the $14^{\text {th }}$ plan but the achievement was 18.7 percent. Similarly, the $15^{\text {th }}$ plan has been launched with the expectation of reducing absolute poverty from 18.7 percent to 11 percent and the population living in multidimensional poverty from 28.6 percent to 13 percent. We can say that there is significant contribution of foreign employment for poverty alleviation in Nepal. The reduction of poverty in different plan periods is one of the impacts of remittance coming from foreign employment.

Thus there has been significant contribution of foreign employment and the incoming remittances on Nepalese society, families income has increased from remittance; families receiving remittances has a tendency to migrate from villages to urban areas where they spend money for luxuries lifestyle. Growing towns and cities across the country is an indicator of money spent in better living and little of the remittance has been mobilized into nation's infrastructure development.

\section{Conclusions}

Foreign employment is the source of remittance which has played a vital role in poverty reduction and expansion of economic activities in Nepal. The increase in remittance results availability in foreign currency in the domestic market and raises national savings. The remittances play in attaining macro-economic stability in the country. There is positive correlation between foreign employment and remittance. It means, foreign employment and remittance are highly associated. The finding of regression analysis between foreign employment and remittance indicates that foreign employment is a significant predictor of remittance. Though increasing remittance has its own advantage, it would eventually lead to economic failure if the flow of remittance is disrupted. There is a massive leakage in actual remittance inflow because most of labor prefers to send their earning through the informal channels. So, government should make plans to encourage the migrants to follow the formal channels to send their earning.

More Nepalese workers are accepted in East and South Asia as well as the Gulf countries because of their low skills and cheap wage-payment and also, they be ready to do whatever job is given to them. Government should improve the curriculum in school so that it can provide more practical based knowledge; conduct consultation meetings with the experts, occupation groups, trade unions and foreign employment enterprises to make rules and regulations for 
the promotion and management of foreign employment occupation. Government should monitor the manpower agencies providing foreign employment services for their efficiency and transpiring. There are many incidences of fake employment contracts, visas and forged documents etc. So effort should to make foreign employment business safe, well-managed and decent as well as protect the rights and interest of foreign bound workers and foreign employment entrepreneurs.

\section{Appendix}

Appendix-I: Ratio of Remittance to GDP from 2001/02 to 2018/19

\begin{tabular}{|l|c|c|c|c|c|}
\hline FY & $\begin{array}{c}\text { Foreign } \\
\text { Employment }\end{array}$ & $\begin{array}{c}\text { Growth Rate } \\
\mathbf{( \% )}\end{array}$ & $\begin{array}{c}\text { Remittance (Rs. } \\
\text { in Billion) }\end{array}$ & $\begin{array}{c}\text { Growth Rate } \\
\mathbf{( \% )}\end{array}$ & $\begin{array}{c}\text { Ratio of } \\
\text { Remittance to GDP }\end{array}$ \\
\hline $2001 / 02$ & 242005 & - & 47.22 & $0.7 \%$ & $10.3 \%$ \\
\hline $2002 / 03$ & 347062 & $43.41 \%$ & 47.54 & $0.67 \%$ & $11.0 \%$ \\
\hline $2003 / 04$ & 435722 & $25.54 \%$ & 54.20 & $14.01 \%$ & $10.9 \%$ \\
\hline $2004 / 05$ & 591400 & $35.73 \%$ & 58.59 & $8.10 \%$ & $11.1 \%$ \\
\hline $2005 / 06$ & 773592 & $30.80 \%$ & 65.54 & $11.86 \%$ & $14.9 \%$ \\
\hline $2006 / 07$ & 978125 & $26.44 \%$ & 97.69 & $49.05 \%$ & $13.8 \%$ \\
\hline $2007 / 08$ & 1227166 & $25.46 \%$ & 100.14 & $2.50 \%$ & $17.4 \%$ \\
\hline $2008 / 09$ & 1459626 & $39.24 \%$ & 183.01 & $82.75 \%$ & $21.2 \%$ \\
\hline $2009 / 10$ & 1753720 & $20.15 \%$ & 231.7 & $10.50 \%$ & $19.4 \%$ \\
\hline $2010 / 11$ & 2055685 & $17.22 \%$ & 253.6 & $9.42 \%$ & $18.5 \%$ \\
\hline $2011 / 12$ & 2437111 & $18.55 \%$ & 359.6 & $41.81 \%$ & $23.5 \%$ \\
\hline $2012 / 13$ & 2852929 & $17.06 \%$ & 434.6 & $20.86 \%$ & $25.6 \%$ \\
\hline $2013 / 14$ & 3164491 & $10.92 \%$ & 543.29 & $25.01 \%$ & $27.7 \%$ \\
\hline $2014 / 15$ & 3201268 & $01.16 \%$ & 617.27 & $13.62 \%$ & $29.0 \%$ \\
\hline $2015 / 16$ & 3619981 & $13.08 \%$ & 665.06 & $7.74 \%$ & 29.5 \\
\hline $2016 / 17$ & 4003474 & $10.60 \%$ & 695.50 & $4.58 \%$ & 26.0 \\
\hline $2017 / 18$ & 4365415 & $9.04 \%$ & 755.10 & $8.57 \%$ & 24.8 \\
\hline $2018 / 19$ & 4601708 & $5.41 \%$ & 879.3 & $16.45 \%$ & $25.4 \%$ \\
\hline
\end{tabular}

Source: Various Economic Surveys (2001/02-2019/20) and Quarterly Economic Bulletin 2019/20, Nepal Rastra Bank.

\section{References}

Department of Foreign Employment (2011). Annual Report of Department of Foreign Employment. Government of Nepal, Kathmandu, Nepal.

Ebeke, C. H. (2010). Remittances, Value-added Tax and Tax Revenue in Developing Countries. CERDI Working Paper 201030. France: Centre d'Etudeset de Recherchessur le Développement International, Clermont-Ferrand.

Gaudel, Y.S .(2006).Remittance Income in Nepal: Need for Economic Development. The Journal of Nepalese Business Studies, Vol.3, No.1,pp.9-17. 
Gibson, J., \& McKenzie, D. (2012). The Economic Consequences of 'Brain Drain' of the best and Brightest: Microeconomic Evidence from Five Countries. Economic Journal, 122, pp.339-375.

Ministry of Labour and Employment. (1999). National Labour Policy 1999. Kathmandu: Government of Nepal.

Kafle, R.R. (2018). Relationship between Remittance and Economic Growth in Nepal. Tribhuvan University Journal, 32(2), pp.249-266.

Lambert, P.J. (1989). Distribution and Redistribution of Income: A Mathematical Analysis. Cambridge: Basil Blackwell Inc.

Ministry of Finance. (2010). Economic Survey 2010/11. Government of Nepal, Kathmandu. . (2014). Economic Survey 2014/15. Government of Nepal, Kathmandu. . (2018). Economic Survey 2018/19.Kathmandu: Government of Nepal. . (2019). Economic Survey 2019/20. Government of Nepal, Kathmandu.

Ministry of Labour and Employment (1985). Nepalese Foreign Employment Act 1985. Government of Nepal, Kathmandu, Nepal.

Ministry of Labour \& Employment (2005). The Labour and Employment Policy 2005. Government of Nepal, Kathmandu, Nepal.

Ministry of Labour and Employment. (2011). Foreign Employment Policy 2011. Government of Nepal, Kathmandu, Nepal.

Muller, N.S. \& Thieme, S. (2007). Livelihood Strategies in a Marginal Area of Nepal. Issues in Geographical Marginality.

Nepal Rastra Bank. (2002).Foreign Employment and the Remittance Economy of Nepal. Kathmandu, Nepal. . (2019). Quarterly Economic Bulletin 2019/20. Research Department Publication Division, Baluwatar, Kathmandu.

Panta, B. (2011). Harnessing Remittances for Productive Use in Nepal. Economic Review,23. pp.1-20.

Shrestha, B.(2008). Contribution of Foreign Employment and Remittances to Nepalese Economy. Economic Review, 20. pp.1-15.

Shrestha, B. (2004). Nepalese Economy. Kathmandu: New Hira Enterprises, Kirtipur.

Thieme, S.(2004). Financial Self-help Associations among far West Nepalese Labour Migrants in Delhi. Asian and Pacific Migration Journal, 13(3).pp.339-361. 